\title{
ACCOUNTING TREATMENT OF BIOLOGICAL ASSETS AND AGRICULTURAL PRODUCTS
}

\author{
Rubén Dario Marrufo Garcia \\ Dr. Rafael Belloso Chacin University \\ Faculty of Administrative Sciences \\ Maracaibo, Zulia State, Venezuela \\ rmarrufo@urbe.edu.ve
}

\author{
Abel Maria Cano Morales \\ University of Medellin \\ Faculty of Economic and Administrative Sciences \\ Medellin, Antioquia, Colombia. \\ amcano@udem.edu.co
}

Reception date: 10/13/2020 - Revision date: 01/11/2021 - Approval date: 01/20/2021

DOI: https://doi.org/10.36995/j.visiondefuturo.2021.25.02R.002.en

\begin{abstract}
It should be mentioned that this work that is presented, as a result of research, corresponds to the management and accounting treatment that can be given to Biological Assets in Latin American companies in the agricultural sector, and its purpose is to demonstrate the influence that exists between the importance given to low financial accounting (IAS / IFRS) and poor reciprocity in accounting management and accounting practices that are effectively applied in the agricultural sector, especially in SMEs, thereby causing some cracks. However, it can be stated that the reasons for the possible fissures that may exist are attributed to the fact that the current general accounting standards do not adapt very well to the particularities of the agriculture sector and are relatively difficult, and costly to implement.
\end{abstract}

KEY WORDS: Biological Assets; Farm products; Colombian farms; Accounting Standards.

\section{INTRODUCTION}

The purpose of this article is to give greater clarity, it is necessary to mention that International Accounting Standard 41. (IAS 41), when they are full and section 34 for SMEs, prescribe the accounting treatment of agricultural activity, introducing significant advances in the recognition of the results of the transformation of biological assets generated in the joint effort of human beings and nature. It should be noted that in the accounting treatment of biological assets, man is an important but not necessary element for this process to take place. Because (IAS 41) only considers biological goods whose result is the product of man and nature. In this sense, many companies, farms, large estates, among others,

Now, with the entry into force of international financial information standards in Colombia, it is of vital importance that companies engaged in the exploitation of biological assets such as (Sheep, Trees, Plants, Pigs, Shrubs, vines, fruit trees among others). Adjust your accounting to show the true financial condition of this type of business. In addition, they comply with Law 1314 of 2009, the Colombian Government seeks to use a unique financial language of high 
quality, understandable and exact compliance, with the application of international financial reporting standards it is vitally important to evaluate the effects in the preparation and presentation of financial statements, as well as comparison with existing standards, Cano (2010).

In this sense, in order to have good accounting and financial information, knowledge of the biological asset is required from its gestation to its maturity, since all the disbursements that occur in the growth stage will be carried to an account of the financial situation statement. in the non-current asset category called growing biological asset, which is meant to express the costs associated with the growth of the plant and / or animal, as they are; Direct and indirect labor, supplies, inputs, fees among others will not be recorded in a nominal account, when the plant and / or animal are already in their reproductive maturity, the growing biological asset account is reclassified to an account called biological asset. in production, when that happens,

Due to the aforementioned, it is necessary to have a good internal control, regarding the management of inventories, because the requisition that is made in the warehouse, the associated biological asset must be specified, that is, if it is for the stage of Growth will be debited to the growing biological asset account against a credit to inventory, if it is in the production stage, a debit to the expense account associated to production will be given against a credit to inventory. In this sense, the organization's management must create cost centers, for each stage that occurs in the harvest and / or breeding of the animal, in order to have the costs identified for each activity.

On the other hand, when talking about the application of (IFRS), within the farms, it is not only having knowledgeable personnel in the accounting or financial area, or complying with all current regulations. Beyond these aspects, all organizations are showing that they have been impacted on their businesses by this process of applying (IFRS), and who more than the companies themselves supported in their administrative management, to determine the variations of their business model, and the influence of this regulation on its planning in a transversal and holistic way.

It should be noted that the agricultural activity presents a discrepancy with other activities carried out by the business units to achieve profit, hence the comparative analysis of the standards currently applied for the information on agricultural activity and the revision of the accounting treatment current agricultural activity under the International Financial Reporting Standards (IFRS), have been the starting point of this research. Therefore, this segment serves as the basis for the development of own research in which it is attempted to identify the aspects determined in the agricultural production process, biological assets and biological

\footnotetext{
"Visión de Futuro" Año 18, Volumen No 25 N², Julio - Diciembre 2021 - Pág 63 - 80 URL de la Revista: http://visiondefuturo.fce.unam.edu.ar/index.php/visiondefuturo/index

URL del Documento: https://visiondefuturo.fce.unam.edu.ar/index.php/visiondefuturo/issue/view/21

ISSN 1668 - 8708 - Versión en Línea

E-mail: revistacientifica@fce.unam.edu.ar
} 
transformation. Some more practical methods for recognition, measurement and reporting are also offered as an alternative to current treatments.

It is certainly necessary to clarify that, over the last decade, there has been a proliferation of accounting pronouncements indicating that the authors of accounting standards around the world are progressively abandoning the traditional historical cost model and are actively propagating the paradigm of value. reasonable. In this sense, (Barlev and Haddad 2003). They argue that accounting under the fair value method has the ability to improve the organizational administrative function, by providing relevant information to interested parties, thus appeasing social controversies. Which allow us to argue that, far from reducing conflict and alienation in the agricultural sector, the fair value approach is based on neoclassical economic ideals that are not conducive to emancipatory accounting, all based on the notion raised by Carl Marx in Capital, and which tacitly says: "Marx breaks with these conceptions by stating in Capital that use value and value determinations are not the source of fetishism: The mystical character of the merchandise does not, therefore, derive from its use value. Nor does it come from the content of the value determinations". (Marx, 2002, p. 87)", which is why commodity fetishism is mentioned, and allows us through this document to analyze the ideological role of the International Accounting Standard (IAS 41) in legitimizing conflicts social in the context of fair trade of agricultural enterprises,

Therefore, our job consists ofobserve the preexistence of some fissures between the importance given to accounting and the low level of accounting and accounting practices that are actually applied in the agricultural sector. However, it can be stated that the reasons for these fissures are attributed to the fact that the current general accounting standards do not adapt very well to the particularities of agriculture and are relatively difficult and costly to implement. Therefore, the Agricultural accounting information from the database of the national agricultural exchange and the International Accounting Standard for Agriculture (IAS 41) is suggested, since they become key elements to improve the use of accounting on farms. Colombian,

Finally, the definitions and approaches of the main authors regarding International Financial Reporting Standards, biological Assets and their initial, and subsequent recognition, of agricultural Products, of Measurement are presented in the light of section 34, of the Estimated Costs of the Point of Sale, and of the Determination of the Fair Value and of the accounting records of a Soursop Harvest as an example, and finally present the proposals of some authors on the methodology to be followed for the Valuation of the assets Biological, to finally conclude how the accounting treatment of biological assets and agricultural products should be, on the other hand it is presented as an important conclusion as this type of 
economic activity,and the implementation of IFRS is important because its standards are closer to reality, which facilitates the accounting process of biological assets, and decisionmaking.

\section{DEVELOPMENT}

\subsection{Definition of International Financial Reporting Standards}

It is necessary to mention that the research carried out has as its main objective, to analyze the accounting treatment of biological assets and agricultural products, making it clear that agricultural activity is compared to other commercial activities that depend on natural and environmental conditions. different, therefore this implies that recognizing that any agricultural activity that is carried out is closely linked to the geographical position where it is carried out, which is why through the work carried out, it is intended to identify possible impediments that may arise in the application practice of International Accounting Standard 41 (IAS 41) and refer to possible solutions to overcome them, In the same way, it should be mentioned that this work is based on the main theoretical postulates of (Bastián. 2008), (Corona. 2014), (NIC 41), among other authors, and is framed under a descriptive, documentary, and analytical methodology using the hermeneutics on the accounting treatment of biological assets.

However, and for the convenience of readers, we will cite some definitions around the International Financial Reporting Standards from now on (IFRS) and from the International Accounting Standards from now on (IAS), according to (Romero 2011), states that International Standards Financial Reporting Standards (IFRS) and International Accounting Standards (IAS) are a set of Standards, laws as well as principles that establish the information in which financial statements must be presented, as well as the way in which this information should be presented in said states. For their part (Warren, Reeves and Duchac. 2015), states that the IAS-IFRS is an accounting model that takes as its starting point the accounting principle of the operating entity,

For their part, (Besteiroy Marracín. 2011), they say that International Financial Reporting Standards concern a unique set of enforceability standards, globally accepted, understandable as well as high quality, based on principles in an articulated manner; They urge that financial statements have comparable, transparent, as well as high-quality information that helps investors and other users to make economic decisions. For the purpose of this research, a position is established with Romero (2011), who states that the International Financial Reporting Standards (IFRS) and International Accounting Standards (IAS) are a set of Standards and laws.

\footnotetext{
"Visión de Futuro" Año 18, Volumen No 25 N², Julio - Diciembre 2021 - Pág 63 - 80 URL de la Revista: http://visiondefuturo.fce.unam.edu.ar/index.php/visiondefuturo/index

URL del Documento: https://visiondefuturo.fce.unam.edu.ar/index.php/visiondefuturo/issue/view/21

ISSN 1668 - 8708 - Versión en Línea

E-mail: revistacientifica@fce.unam.edu.ar
} 
Likewise, (Romero. 2011), (Warren and Col. 2007), (Besteiroy Marracín 2011), assume the position on the importance of International Financial Reporting Standards, IFRS in companies, determined that users of these standards, require a standard level of information to be able to classify and evaluate your company, that is, it helps the impact of IFRS to be reflected in their productivity and in compliance with the Laws that govern Accounting.

For the purpose of this research, a position is established with (Romero. 2011), who states that the International Financial Reporting Standards (IFRS) and International Accounting Standards (IAS) are a set of Standards and laws. Now, from the positions of the authors, if it infers that Colombian agricultural producers adopt International financial information standards, complying with what is established by law 1314 of 2009, they will also show financial information with more clarity for shareholders and those who require information from the company.

\subsubsection{International Accounting Standard No.41. Agriculture, and the accounting treatment of "Biological Assets"}

It is fair to mention that IAS 41 "Agriculture" aims to establish standards for accounting treatment, presentation in financial statements and information to be disclosed in relation to agricultural activity. IAS 41 applies to the following items as long as they are related to agricultural activity:

1. Biological assets.

2. Agricultural products at the point of harvest or collection.

3. Government subsidies related to agricultural activity.

However, it is important to note that IAS 41 only applies up to the point of harvest. From that moment on, production, as well as the manufacturing processes that use agricultural products as raw materials, will be governed by the provisions of IAS 2 "Inventories". On some occasions, the inclusion of certain agricultural products under IAS 41 is not clear and it is necessary to know their destination, which will be the one that defines whether IAS 41 or IAS 2 is applied.

It is worth mentioning that agricultural activity is defined in (IAS 41) as the management by an entity of the transformation and collection of biological assets to use them for sale, to convert them into agricultural products or other additional biological assets. Agricultural activity in its different forms, namely (forestry, livestock, among others) has three common characteristics:

A. Change capacity. Both plants and animals are capable of undergoing biological transformations.

\footnotetext{
"Visión de Futuro" Año 18, Volumen No 25 N², Julio - Diciembre 2021 - Pág 63 - 80

URL de la Revista: http://visiondefuturo.fce.unam.edu.ar/index.php/visiondefuturo/index

URL del Documento: https://visiondefuturo.fce.unam.edu.ar/index.php/visiondefuturo/issue/view/21

ISSN 1668 - 8708 - Versión en Línea

E-mail: revistacientifica@fce.unam.edu.ar
} 
B. Change management. Management facilitates biological transformations by promoting the conditions necessary for the transformation to take place.

C. Measurement of change. both the qualitative and quantitative change resulting from the biological transformation is measured and controlled systematically by management.

\section{What are biological assets and what is their accounting treatment}

It is worth mentioning that (Mora 2008), states that they are the living animals and plants that are controlled by a company as a result of past events. Biological assets include those controlled by their possession and those of a legal or similar arrangement are also recognized as assets according to other regulations. Within biological assets, those that are themselves the primary product, that is, a consumable biological asset, can be distinguished from those that are not themselves the primary product, but rather those that generate said products, for example, trees fruit trees, cattle. A distinction is also made, for accounting purposes, between mature biological assets, when they are ready to be harvested, and immature when they are not yet harvestable.

For his part, (Bastián 2008), states that biological assets are plants as well as living animals that are capable of undergoing biological transformations, in order to give agricultural products, these are accounted for as stocks or to convert them into other biological assets different On the other hand (Corona 2014), it states that it is the management by an entity of the biological transformations and harvests of biological assets to be used for sale, to convert them into agricultural products or other additional biological assets. According to IFRS 13, harvested or collected agricultural products that come from biological assets of an entity will be measured at fair value less costs to sell at the point of harvest or collection.

The International Accounting Standards Board (2010), states that it is a living animal or a plant. According to the Dictionary of Accounting, Auditing and Management Control (Mora. 2008) biological assets represent a live animal or a plant, which are controlled by a company as a result of past events. Regarding the recognition of biological assets, the International Accounting Standards Board (2011) states that the entity will recognize a biological asset or an agricultural product under the following conditions:

The entity controls the asset as a result of past events;

1. It is probable that future economic benefits associated with the asset will flow to the entity;

2. The fair value or cost of the asset can be measured reliably.

\footnotetext{
"Visión de Futuro" Año 18, Volumen No 25 N², Julio - Diciembre 2021 - Pág 63 - 80 URL de la Revista: http://visiondefuturo.fce.unam.edu.ar/index.php/visiondefuturo/index

URL del Documento: https://visiondefuturo.fce.unam.edu.ar/index.php/visiondefuturo/issue/view/21

ISSN 1668 - 8708 - Versión en Línea

E-mail: revistacientifica@fce.unam.edu.ar
} 
On the other hand, (Figuera 2018), states that a company must recognize a biological asset or agricultural product when:

a) The company controls the asset as a result of past events.

b) A future economic benefit associated with the asset is likely to flow to the company.

3. The fair value or cost of the asset can be measured reliably.

In such a way, that, differentiating the exposed approaches, a similarity is observed between the contexts given for the recognition of biological assets: control of the asset, the flow of economic benefits, the cost or value which must be reliably measured. The measurement of biological assets, according to IAS 41, must be carried out at fair value less the costs of the point of sale. The fair value is obtained by discounting the transportation costs and other unavoidable costs to the market value to transfer the production to the marketing center, that is, the costs to the point of sale. Indeed, the fair value of the same asset may not be the same for all entities, or within the same, if it has fields in distant locations. Since your geographic location influences, as well as the proximity or not to the sales positions of the products. The agricultural products obtained must be measured at the harvest or collection site at fair value less the estimated costs up to the point of sale, In the event that the biological asset is in a growth and / or development stage, for which There are no market prices, these will be calculated as fair value by applying the present value of the net cash flows.

\section{Recognition and measurement of Biological Assets}

It is necessary to mention that for the recognition of biological assets it must comply with the three conditions established in the conceptual framework and that it reads verbatim, for the recognition of assets it is necessary:

1. That the entity controls the asset as a result of past events.

2. It is probable that the entity will receive the future economic benefits associated with the asset.

3. The fair value or cost of the asset can be measured reliably.

However, we must mention that the valuation criterion establishes that all biological assets will be recognized at fair value, at fair value less costs to sell. And sales costs should include:

A. Commissions paid to intermediaries.

B. Liens and taxes.

On the other hand, the Standard establishes that in no case should transportation or similar costs be included in determining the fair value of the biological asset. On the other hand, there may be contracts for the future sale of a biological asset. The prices set in said

\footnotetext{
"Visión de Futuro" Año 18, Volumen No 25 N² 2, Julio - Diciembre 2021 - Pág 63 - 80 URL de la Revista: http://visiondefuturo.fce.unam.edu.ar/index.php/visiondefuturo/index

URL del Documento: https://visiondefuturo.fce.unam.edu.ar/index.php/visiondefuturo/issue/view/21 
contract may in no case be taken as a basis for determining fair value. IAS 41 establishes the presumption that the fair value of the asset can be estimated reliably. When determining fair value there may be 3 situations:

1. Existence of an active market. In this case, the listed price in said active market is the appropriate basis for determining the fair value of the asset. For example, in the case of cereals or sugar, there are spot markets in which the price of the raw material is determined, which should serve as the basis for the valuation of said biological assets.

2. Lack of an active market. In this case, for the determination of fair value as a reference the following information:

a. The price of the most recent transaction in the market, provided that the conditions have not changed from the date of the transaction to the date of the reporting period.

b. Market prices of similar assets, adjusted to reflect existing differences.

3. Impossibility of determining fair value. In this case, the biological asset must be measured at its cost price corrected for depreciation and impairment, exclusively at the time of its recognition.

Finally, it is common for biological assets to be presented in combination with other types of assets. For example, in a soybean plantation the land is combined with the soybean plant (biological asset). For the valuation of this type of biological asset, the entire holding can be taken as fair value and the value of the combined land can be deducted separately.

\section{Recognition of gains and losses}

It should be noted that IAS 41 establishes that gains or losses both on the initial recognition of a biological asset and changes in its fair value will be recorded in the income statement, never in equity.

On the other hand (Bastián 2008), states that a biological asset must be valued, at the time of its initial recognition, as well as on the closing date of each balance, according to its fair value, discounting the estimated costs at the point of sale, provided that fair value cannot be reliably determined.

Therefore, it has to be taken into account, the time of carrying out the initial measurement of the biological assets in their inception phase, a series of disbursements when the biological asset is under development, such as the associated costs from food, veterinary, among others, are not recognized in the result if not in a biological asset under development account.

\footnotetext{
"Visión de Futuro" Año 18, Volumen No 25 N², Julio - Diciembre 2021 - Pág 63 - 80 URL de la Revista: http://visiondefuturo.fce.unam.edu.ar/index.php/visiondefuturo/index

URL del Documento: https://visiondefuturo.fce.unam.edu.ar/index.php/visiondefuturo/issue/view/21

ISSN 1668 - 8708 - Versión en Línea

E-mail: revistacientifica@fce.unam.edu.ar
} 
Likewise, the entity that had previously valued the biological asset as its fair value less the estimated costs at the point of sale, will continue to do so until the moment of its sale.

Now, the initial and subsequent measurement of a biological asset is illustrated with the following example. Let us suppose that a company dedicated to raising cattle on February 2, 2015 acquires two steers of two and three years of age, at the cost of 2,000 .000 pesos, each and on May 31 of that same year, balanced meals were bought for a value of 3,200,000 pesos plus VAT of $16 \%$, an input that was consumed by the growing copies, in addition 500,000 pesos are paid for fees of veterinarian plus VAT of $16 \%$ on the same day as of the closing date, the fair value of the aforementioned animals, in view of their biological evolution is 800,000 pesos each, at which time it reaches the category of bulls due to age change, according to Marrufo and Chirino (2017).

Table No.1. Initial recognition

\begin{tabular}{|c|c|c|c|c|}
\hline Date & Accounts and Explanation & Reference & Should & To have \\
\hline 02-02-2018 & $\begin{array}{c}\text { AO-01 } \\
\text { Biological Assets in Development }\end{array}$ & MA-01 & $4,000,000$ & \\
\hline & $\begin{array}{l}\text { Accounts Payable P / r Purchase of two } \\
\text { steers }\end{array}$ & MA-02 & & $4,000,000$ \\
\hline 05-31-2018 & $\begin{array}{c}\text { AO-02 } \\
\text { Biological Assets in Development }\end{array}$ & MA-01 & $3,200,000$ & \\
\hline $05-31-2018$ & VAT - Shopping & MA-03 & 512,000 & \\
\hline 05-31-2018 & $\begin{array}{l}\text { Accounts Payable P / } r \text { Purchase of feed } \\
\text { for growing steers }\end{array}$ & & & $3,712,000$ \\
\hline $05-31-2018$ & $\begin{array}{c}\mathrm{AO}-03 \\
\text { Biological Assets in Development }\end{array}$ & MA-01 & 500,000 & \\
\hline 05-31-2018 & VAT - Shopping & MA-04 & 80,000 & \\
\hline $05-31-2018$ & Debts to pay & MA-02 & & 580,000 \\
\hline
\end{tabular}

Source: Own elaboration (Marrufo \& Cano 2019)

\footnotetext{
"Visión de Futuro" Año 18, Volumen N$^{\circ} 25$ N 2, Julio - Diciembre 2021 - Pág 63 - 80

URL de la Revista: http://visiondefuturo.fce.unam.edu.ar/index.php/visiondefuturo/index

URL del Documento: https://visiondefuturo.fce.unam.edu.ar/index.php/visiondefuturo/issue/view/21

ISSN 1668 - 8708 - Versión en Línea

E-mail: revistacientifica@fce.unam.edu.ar
} 
Table No.2. Later recognition

\begin{tabular}{|c|l|c|c|c|}
\hline Date & \multicolumn{1}{|c|}{ Accounts and Explanation } & Reference & Should & To have \\
\hline $\begin{array}{c}12-31- \\
2018\end{array}$ & \multicolumn{1}{|c|}{ AO-04 } & MA-05 & $7,700,000$ & \\
\hline $12-31-$ & $\begin{array}{l}\text { Biological Assets in Production } \\
\text { reclassification of Biological Assets in } \\
2018\end{array}$ & Development to Production. & & $7,700,000$ \\
\hline $12-31-$ & \multicolumn{1}{|c}{ AO-04 } & MA-05 & $1,600,000$ & \\
2018 & Biological Assets in Production & MA-06 & & $1,600,000$ \\
\hline $12-31-$ & $\begin{array}{l}\text { Gain on Non-financial Assets at Fair Value P } \\
2018\end{array}$ & $\begin{array}{l}\text { r record of fair value of biological assets in } \\
\text { production }\end{array}$ & & \\
\hline
\end{tabular}

Source: Own elaboration (Marrufo \& Cano 2019)

As seen in the example, all the costs associated with the development of the steers will be part of the biological asset under development, until they reach their reproductive maturity, once their maturity is reached, the biological asset under development is reclassified, giving it a debit in this case to the biological asset in production since it is in its maturity and reproductive stage, from there all the costs of labor, food, among others, will be recognized in an income statement.

\section{Recognition and Measurement of Agricultural Products}

According to IAS 41, it is the product already collected, coming from the company's biological assets. Likewise (Bastián 2008), it states that they are the harvests collected from the biological assets of a company, which must be valued at the point of harvesting according to their fair value less the costs of sale.

\footnotetext{
"Visión de Futuro" Año 18, Volumen No 25 N², Julio - Diciembre 2021 - Pág 63 - 80

URL de la Revista: http://visiondefuturo.fce.unam.edu.ar/index.php/visiondefuturo/index

URL del Documento: https://visiondefuturo.fce.unam.edu.ar/index.php/visiondefuturo/issue/view/21

ISSN 1668 - 8708 - Versión en Línea

E-mail: revistacientifica@fce.unam.edu.ar
} 

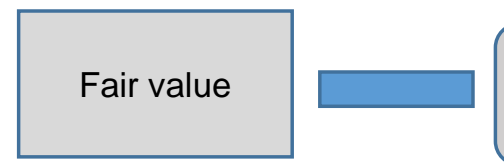

$$
\text { Cost of Sale }
$$

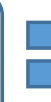

VALUE IN THE FINANCIAL STATEMENTS OF BIOLOGICAL ASSETS OR AGRICULTURAL PRODUCTS

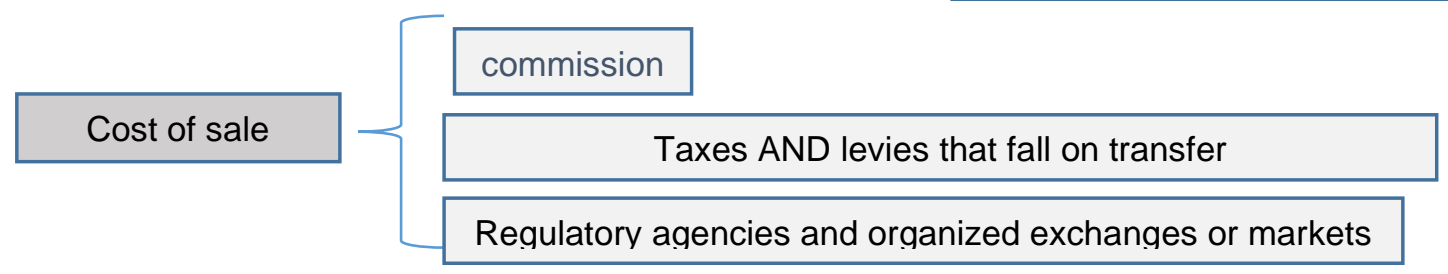

Transportation costs are excluded

Other costs necessary to bring the assets to market are excluded

Figure No.1. Accounting systems for biological assets and application IAS 41 Source: Elaboration based on Rincón Ángel (2017).

From the accounting point of view, it is of great importance that Colombian agricultural companies take into account the fair value of biological assets, discounting the cost of sale in order to obtain the fair value in the financial statements, according to raised the cost of sale should include commissions, taxes and levies, organized markets among others.

\section{Measurement of Agricultural Products}

As established in Section 34 (2015), an entity will measure a biological asset at the time of initial recognition and on each reporting date at its fair value less costs to sell. To determine the fair value, an entity will consider the following:

A. If there is an active market for a certain biological asset or for an agricultural product in its current location and conditions.

B. If there is no active market, an entity will use one or more of the following information: Price of the most recent transaction in the market, market price of similar assets, as well as a sector reference.

C. In some cases, fair value can be easily determined, without undue cost or effort, even when no market-determined prices or values are available for a biological asset in its current condition.

From a pragmatic point of view (Warren, Reeves and Duchac. 2015), the following example is shown, of how administrators and accountants of companies in the agricultural sector in Colombia must recognize and measure agricultural products in the financial statements.

\footnotetext{
"Visión de Futuro" Año 18, Volumen N²5 N², Julio - Diciembre 2021 - Pág 63 - 80 URL de la Revista: http://visiondefuturo.fce.unam.edu.ar/index.php/visiondefuturo/index

URL del Documento: https://visiondefuturo.fce.unam.edu.ar/index.php/visiondefuturo/issue/view/21 
The company Fruits del Valle, CA, is dedicated to the cultivation of soursops, has in 2015, plantations with trees of the biological family Annonaceae, whose fruit is the soursop. For the 2016 harvest, you want to determine the cost of said fruit, having as a reference that in the market the cost of the harvest is $\$ 10,500$ pesos in the same way "FRUTOS EL PUMAREJO" incurred harvest costs in $\$ 5,000$ pesos, which is registered in the account of existence of crops in soursop processes. On the other hand, the estimated costs of the point of sale of $\$ 4,500$ peso are as follows:

Table No. 3. Estimated costs of the Point of Sale

\begin{tabular}{|l|r|}
\hline \multicolumn{1}{|c|}{ COSTS } & \multicolumn{1}{|c|}{ AMOUNT } \\
\hline Transportation Costs & \\
\hline Other Costs to Place on the Market & 350.00 \\
\hline Commission of Intermediaries & $1,200.00$ \\
\hline Product Market Expenses & 780.00 \\
\hline Taxes and Duties & 950.00 \\
\hline Other Estimated Costs & 270.00 \\
\hline Total Costs & $\mathbf{4 , 5 0 0 . 0 0}$ \\
\hline
\end{tabular}

Source: Own elaboration (Marrufo \& Cano 2019)

Table No. 4. Determination of the Fair Value of the Soursop Harvest

\begin{tabular}{|l|r|}
\hline Fair Value of Soursop Harvest & $10,500.00$ \\
\hline Less Transportation Costs & -950.00 \\
\hline Other Costs to Place on the Market & -350.00 \\
\hline Commission of Intermediaries & $-1,200.00$ \\
\hline Product Market Expenses & -780.00 \\
\hline Taxes and Duties & -950.00 \\
\hline Other Estimated Costs & -270.00 \\
\hline HARVEST VALUE & $6,000.00$ \\
\hline Soursop Harvest Value & $6,000.00$ \\
\hline Less Real Cost of Harvest & $-5,000.00$ \\
\hline Cost Adjustment & $\mathbf{1 , 0 0 0 . 0 0}$ \\
\hline
\end{tabular}

Source: Own elaboration (Marrufo \& Cano 2019)

\footnotetext{
"Visión de Futuro" Año 18, Volumen No 25 Nº 2, Julio - Diciembre 2021 - Pág 63 - 80 URL de la Revista: http://visiondefuturo.fce.unam.edu.ar/index.php/visiondefuturo/index

URL del Documento: https://visiondefuturo.fce.unam.edu.ar/index.php/visiondefuturo/issue/view/21 
Table No. 5. Accounting Record

\begin{tabular}{|c|c|c|c|c|}
\hline Date & Accounts and Explanation & Reference & Should & To have \\
\hline $\begin{array}{l}12-31- \\
2018\end{array}$ & $\begin{array}{ll} & \mathrm{AO}-01 \\
\text { Soursop harvest } & \end{array}$ & MA-01 & 6,000 & \\
\hline $\begin{array}{l}12-31- \\
2018\end{array}$ & Crops in Process of soursop & MA-02 & & 5,000 \\
\hline $\begin{array}{l}12-31- \\
2018\end{array}$ & $\begin{array}{l}\text { Gain from Change in Fair Value } \\
\mathrm{P} / \mathrm{r} \text { Now the value of the Soursop Harvest is } \\
\text { equivalent to } \$ 6,000 \text {, from now on this } \\
\text { account will be transferred to the inventory } \\
\text { account and number } 2 \text { will be applied in the } \\
\text { case for full NICs and for SMEs section } 13 \\
\text { whose cost will be the value indicated above. }\end{array}$ & MA-03 & & 1,000 \\
\hline
\end{tabular}

Source: Own elaboration (Marrufo \& Cano 2019)

As shown in the practical case, the accounting procedure is displayed according to what is dictated by IAS 41 for what is the registration of a soursop harvest from the initial valuation to the subsequent valuation of the same.

\section{Active market}

Indeed, (Accid. 2009) states that the active market is all those goods, services, in which buyers or sellers for a given good or service can be found at any time, and in turn the prices are known and easily accessible to the market. In addition, it reflects actual, current and regularly produced transactions.

For its part (Paraninfo 2007), it says that an active market is one where the following conditions are met: the goods or services exchanged are homogeneous, buyers or sellers for a certain good or service can be found at any time, and the prices are known Easily accessible to the public, these prices also reflect actual, current and regularly produced market transactions.

The axioms that the authors describe coincide, and they also expose in detail the definition of the active market, which allows us to conclude how all those goods and services exchanged, these can be found practically at any time buyers or sellers for a certain good or service, and prices are known, easily accessible to the public.

\footnotetext{
"Visión de Futuro" Año 18, Volumen No 25 N², Julio - Diciembre 2021 - Pág 63 - 80 URL de la Revista: http://visiondefuturo.fce.unam.edu.ar/index.php/visiondefuturo/index

URL del Documento: https://visiondefuturo.fce.unam.edu.ar/index.php/visiondefuturo/issue/view/21 


\section{Valuation of Biological assets}

For (Verón and Marcolini 2011), they state that the generation of controversy over the measurement of fair value in biological assets. According to what was stated by, (Verón \& Macolini 2011), they say that "fair value is a measurement based on the market, not a measurement determined by the entity", it is also measured using assumptions about the participants including risk profile.

For its part (Pabón 2010), it states that the fair value recognizes unrealized gains and losses as well as the prices of a market on the date of presentation of the financial statements, these may be different with the prices at which the assets will be transferred, it is necessary to clarify that the fair value is not taken as an effectively concluded business, these are expressed through a potential business scheme and dial and in this case the reality of the logical changes that are presented to the active.

In the case of colombina producers, they do not have an active market that allows them to reliably measure biological assets, which generates distortions with what the authors say about the valuation of said assets.

\section{Inventories}

Represents the existence of movable and immovable property that the company has to trade with, buying and selling them as is or processing them first before selling them, in a given economic period. According to (Block and Hirt 2015), companies can also apply for loans to get funds, backed with inventory.

In this sense, while the scope with which inventory financing can be used is based on the possibility of negotiation of the pledged goods, the stability associated with their price and the perishable nature of the product. Another significant factor is the degree of physical control that the lender can exercise over the product; some of these factors can be related to the stages of inventory production and the nature of control.

According to (Van Horne and Wachowicz 2012), it reports that inventories represent a reasonably liquid asset and, therefore, appropriate to be used as collateral to request loans; in this case, the lender determines a percentage advance against the market value of the collateral, this percentage varying according to the quality of the inventory. Lenders determine the percentages they are willing to anticipate by considering ease of sale, resistance to impairment, market price stability, and the difficulty and expense of selling inventory to cover the loan.

\footnotetext{
"Visión de Futuro" Año 18, Volumen $\mathrm{N}^{0} 25$ N² 2, Julio - Diciembre 2021 - Pág 63 - 80 URL de la Revista: http://visiondefuturo.fce.unam.edu.ar/index.php/visiondefuturo/index URL del Documento: https://visiondefuturo.fce.unam.edu.ar/index.php/visiondefuturo/issue/view/21 ISSN 1668 - 8708 - Versión en Línea 
As expressed, (Gitman 2014) reports that inventory is generally the second best option after accounts receivable, as collateral for a short-term loan; since it is attractive because it commonly has a market value greater than its book value, which is used to establish its value as collateral. The most important characteristic of inventory, valued as collateral, is its marketability, which must be considered based on its physical properties; In other words, the lender evaluates the inventory as a possible collateral for a loan, looking for products with very stable market prices, that have easy markets and that lack essential physical properties. In consideration of what was expressed by the authors, inventory financing is defined as the request for short-term loans which represents a current asset to obtain funds based on the negotiation of the pledged assets. In the same way it is said that it is a better option after accounts receivable.

In this sense (Cardozo 2016), it states that depending on the biological asset and the jurisdiction specified, there may be an active market in which there is a readily available trading price. In such cases, the cost measurement is usually more burdensome and subject to fair value determination, due to the multiple distributions of all the costs of raising the animal, as well as the distribution of the corresponding indirect costs. However, if there was an active market for two-week-old calves, fair value could be determined. In addition, managements usually manage agricultural activities based on market prices or other current value measures, and not based on historical costs. In these cases,

From the point of view of biological assets, the products derived from these such as milk, fruits, meats among others will not be recognized as biological assets, these will be recognized as inventory, it is imperative that the accountants of the companies in the agricultural sector, take into account the valuation of your inventories as established in section 13 of the IFRS for SMEs, regarding the valuation and measurement of inventories.

\section{Methodology}

This research is part of a descriptive methodology. According to (Tamayo and Tamayo 2012. P25), it includes the description, registration, analysis and interpretation of the current nature, the composition of the processes or phenomena, it works on the realities of events and its fundamental characteristic is to present a correct interpretation.

For their part (Finol and Camacho 2006). It expresses that documentary analysis is the process of searching, selecting, reading, registering, organizing, describing, analyzing and interpreting the data extracted from existing documentary sources around a problem, in order to answer questions in any area of human knowledge.

\footnotetext{
"Visión de Futuro" Año 18, Volumen N²5 N² 2, Julio - Diciembre 2021 - Pág 63 - 80 URL de la Revista: http://visiondefuturo.fce.unam.edu.ar/index.php/visiondefuturo/index URL del Documento: https://visiondefuturo.fce.unam.edu.ar/index.php/visiondefuturo/issue/view/21 
According to the purpose, the research was descriptive, which worked on factual realities and its fundamental characteristic is to present a correct interpretation. For (Hernández, Fernández and Baptista 2010), they propose descriptive research, such as the one that aims to "measure or collect information independently or jointly on the concepts or variables to which they refer". Therefore, the type of descriptive research, leads the researcher towards scientific knowledge from the description of a subject or problem without influencing it. In such a way that it implies at the same time the use of observation with which knowledge is strengthened. For its part, the explanatory research according to (Hernández, Fernández and Baptista 2010), aims to establish the causes of the events, events or phenomena being studied. Explanatory studies go beyond the description of concepts or phenomena or the establishment of relationships between concepts; that is to say, they are aimed at responding to the causes of physical or social events and phenomena. As its name indicates, its interest is focused on explaining why a phenomenon occurs and under what conditions it manifests itself, or why two or more variables are related (P. 83-84)

Analyzing the above, it is understood that descriptive studies seek to develop an image or faithful representation of the phenomenon studied based on its characteristics. Describe in this case the accounting treatment of biological assets and agricultural products. In this article, an exhaustive bibliographic search method was used to approach the existing literature, for which an automated search in databases, review of articles and journals was used, identifying the most prominent authors on the subject.

Regarding the exhaustive search method, according to (Benavent, González, González, and Arroyo. 2011). "It constitutes a fundamental stage of any research project and must guarantee the obtaining of the most relevant information in the field of study, from a universe of documents that can be very extensive." The bibliographic review or state of the art corresponds to the detailed description of a certain topic or technology, but does not include the identification of trends that may pose different scenarios about the development of the technology in question and that allow strategic decisions to be taken (Castellano, Torres, Rossero. 2005). Likewise, an analysis of the information, concepts and theories on the accounting treatment of biological assets and agricultural products was carried out.

\section{CONCLUSIONS}

When analyzing the accounting treatment of biological assets and agricultural products, it is concluded that, in this type of economic activity, the implementation of IFRS is important because its standards are closer to reality, which facilitates the accounting process of biological assets, showing a reliable financial and free from significant errors.

\footnotetext{
"Visión de Futuro" Año 18, Volumen No 25 N², Julio - Diciembre 2021 - Pág 63 - 80

URL de la Revista: http://visiondefuturo.fce.unam.edu.ar/index.php/visiondefuturo/index

URL del Documento: https://visiondefuturo.fce.unam.edu.ar/index.php/visiondefuturo/issue/view/21

ISSN 1668 - 8708 - Versión en Línea

E-mail: revistacientifica@fce.unam.edu.ar
} 
For this reason, it is necessary to keep a control of all the expenditures that occur with the biological assets under development, since these are part of it, in addition they are not recorded in the income statements. On the other hand, it is essential to have knowledge of the market, since these will allow you to know the fair value of the crops.

On the other hand, when analyzing the theories and concepts of the authors on IAS 41, which restarts companies that:

A. Disclose, by group or otherwise, the amount of the change in fair value less costs estimated at the point of sale, which has been included in the net profit or loss for the year and is due to both physical and to changes in prices.

B. That biological transformation produces a variety of changes of Physical type, growth, degradation, production and procreation, in which each of these aspects is observable and valuable. Each of these physical changes has a direct relationship to future economic benefits.

C. That the change in the fair value of a biological asset due to harvest or collection, is also a change of physical type.

D. That agricultural activity is often exposed to natural risks such as those related to the weather or diseases. If an event of this type occurs, giving rise to an item of expenses or income with relative importance, the nature and amount of the same will be disclosed, in accordance with the provisions of IAS 1

Therefore, the Technical Council of Public Accounting (CTCP) expressesthat the agricultural products harvested or collected that come from biological assets must be submitted, at the point of harvest or collection, for their fair value less the costs of sale. Consequently, the standards to which this group belongs according to IAS 41 Group 1. IAS 41, "13 Agricultural products harvested or harvested from biological assets of an entity shall be measured at fair value less costs to sell in the point of harvest or collection. Such measurement is the cost as of that date, when IAS 2. Inventories is applied, or other applicable standards". "For its part, in group 2 IFRS for SMEs, 34.5. Harvested or collected agricultural products that come from an entity's biological assets will be measured at fair value less costs to sell at the point of harvest or collection.

Finally, the companies that handle theHarvested or collected agricultural products that come from biological assets must be submitted, at the point of harvest or collection, for their fair value less costs to sell. The norm indicates that biological assets are divided into consumables and to produce, consumables are made up of agricultural products or sold as biological assets, such as cattle from which meat is obtained or those kept for sale, while The 
biological live to produce are made up of all those who are for production such as cattle for milk production, among others, likewise it shows us that depending on the utility of the same if it is to consume or to produce, they havedifferent ways of being treated in accounting, therefore in section 4 "Statement of Financial Position" of the IFRS for SMEs requires the separate presentation of biological assets recorded at cost less accumulated depreciation and impairment (paragraph $4.2(\mathrm{~h})$ ) and biological assets recorded at fair value through profit or loss (paragraph 4.2 (i)).

Therefore, companies in the agricultural sector must be aware that the continuity of their operations is affected not only by the behavior of the prices of the products they sell, as well as how the transformation of the biological asset (live animals and plants) is managed. , among others), in this case it refers to what they express (Romero 2011), (Warren and Col. 2007), (Besteiro and Marracín 2011), about the importance of IFRS in companies, determined that users of These standards require a standard level of information to be able to classify and evaluate your company.

\section{REFERENCES}

Please refer to articles in Spanish Bibliography.

\section{BIBLIOGRAPHICAL ABSTRACT}

Please refer to articles Spanish Biographical abstract.

\footnotetext{
"Visión de Futuro" Año 18, Volumen No 25 N² 2, Julio - Diciembre 2021 - Pág 63 - 80 